\title{
KAJIAN APOLOGETIS TERHADAP KONTROVERSI KEMANUSIAAN DAN KETIDAKBERSALAHAAN YESUS KRISTUS
}

\author{
Heryson Butar-Butar ${ }^{1}$ ) \\ Institut Agama Kristen Kupang ${ }^{1}$ \\ ${ }^{*}$ Email Correspondence: herysontmbb@gmail.com
}

Abstract: The context of understanding the humanity and innocence of Jesus gave rise a theological controversy. The reason is, the all-perfect God who became human in Jesus Christ is difficult to maintain because He is a limited figure and is considered to have made mistakes. For example Jesus' ignorance regarding the person who touched His robe (Mark 5:30-32 and Luke 8 :45), Jesus' ignorance of what will happen in the last days (Mark 13:27-32), Jesus' mistake in calling Zechariah son of Berechiah (Matthew 23:35; 2 Chronicles 24:20) and the wrong behavior of Jesus who was angry in the Temple (Matthew 21:12-16; Luke 19:45-46; John 2:1516). The purpose of this study is to provide a biblical description in an apologetic frame as a form of refutation of these assumptions. This study uses a qualitative method with an apologetic approach. An understanding of the person of Jesus needs to be seen comprehensively with the context that binds it. The assumptions about Jesus' guilt and ignorance are not substantially based on a comprehensive and credible interpretation.

Keywords: Controversy, God becoming man, the limitations of Jesus, the ignorance of Jesus.

Abstraksi: Konteks memahami kemanusiaan dan ketidakbersalahan Yesus menyisahkan kontroversi teologis. Pasalnya, Allah yang maha sempurna itu yang menjadi manusia di dalam diri Yesus Kristus sulit dipertahankan karena Ia adalah sosok yang terbatas dan dianggap pernah melakukan kesalahan, misalnya ketidaktahuan Yesus berkaitan dengan orang yang menjamah jubah-Nya (Markus 5:30-32 dan Lukas 8:45), ketidaktahuan Yesus mengenai apa yang terjadi di akhir zaman (Markus 13:27-32), kesalahan Yesus dalam penyebutan Zakharia anak Berekhya (Matius 23:35; 2 Tawarikh 24:20) dan kesalahan perilaku Yesus yang marah di Bait Allah (Matius 21:12-16; Lukas 19:45-46; Yohanes 2:15-16). Tujuan dari penelitian ini adalah memberikan gambaran biblika dalam bingkai apologetis sebagai bentuk sanggahan terhadap anggapan-anggapan tersebut. Penelitian ini menggunakan metode kualitatif dengan pendekatan apologetis. Pemahaman tentang pribadi Yesus perlu dilihat secara komprehensif dengan konteks yang mengikatnya. Anggapananggapan mengenai kesalahan dan ketiaktahuan Yesus secara substansial tidak didasarkan pada penafsiran yang komprehensif dan kredibel.

Kata Kunci: Kontroversi, Allah yang menjadi manusia, keterbatasan Yesus, ketidaktahuan Yesus.

\section{PENDAHULUAN}

Sosok Yesus Kristus menjadi tokoh sentral dalam kekristenan dimana

Yesus Kristus dipercaya sebagai Allah yang menjadi manusia. Keberadaan Yesus 
yang dipaparkan para penulis kitab Perjanjian Baru sebagai penggenapan pengharapan mesianik telah mendapatkan kritik, baik dari pihak di luar kekristenan maupun dari dalam kelompok Kristen yang berusaha menyajikan pemikiran bahwa Yesus Kristus bukanlah Allah yang berinkarnasi dalam bentuk manusia. ${ }^{1}$ Perdebatan tentang Yesus Kristus sebagai Allah yang menjadi manusia telah berlangsung lama dan banyak menghasilkan pemikiran tentang Yesus Kristus. ${ }^{2}$ Perdebatan tersebut telah hadir dari catatan penulis Perjanjian Baru yang memaparkan pernyataan Yesus ataupun para Rasul yang menggambarkan Yesus sebagai manusia, walaupun dalam beberapa catatan lainnya Yesus digambarkan sebagai Mesias dan pribadi Ilahi yang mampu mengadakan berbagai mukjizat. Beberapa teolog ada yang berpendapat bahwa penulis awal kitab Injil yaitu Markus menyajikan pemahaman yang kuat bahwa Yesus adalah sosok manusia mulia yang sering disebut sebagai Anak Manusia (The Son of Man) dalam beberapa bagian kitab Injil.

\footnotetext{
1 Michael Horton, "Affirming Moser's Well-Qualified Totus Christus," Pro Ecclesia: A Journal of Catholic and Evangelical Theology 29, no. 1 (Februari 2020): 43, https://doi.org/10.1177/1063851219892188. 'Gerald O'Collins, "The Incarnation," dalam The Incarnation: An Interdisciplinary Symposium on the Incarnation of the Son of God, ed. oleh Stephen T. Davis dan Daniel Kendall (Oxford: Oxford University Press, 2002), x. Brian E. Daley, In the Shadow of the Incarnation: Essays on Jesus Christ in the Early Church in Honor of Brian E. Daley, S.J., ed. oleh Peter W. Martens, 1 ed. (Indiana: University of Notre Dame, 2008), $x$. Oliver Davies, Silence and the Word: Negative Theology and Incarnation, ed. oleh Denys Turner, 1 ed. (Cambridge: United Kingdom, 2004), x. Michelle Chaplin Sanchez, Calvin and the Resignification of the World Creation, Incarnation, and the Problem of Political Theology in the 1559 Institutes (Massachusetts: Harvard Divinity School, 2019), x. Michael C. Rea, ed., Oxford Readings in Philosophical Theology: Trinity, Incarnation, and Atonement, 1 ed., vol. 1 (Oxford: Oxford University Press, 2009), x. Michael, Incarnation and myth: The debate continued, ed. oleh Goulder (London: SCM Press, 1979), x. James D.G. Dunn, Christology in the Making: A New Testament Inquiry Into the Origins of the Doctrine of the Incarnation, 2 ed. (Grand Rapids: William B Eerdmans Publishing Company, 1996), x. Irenaeus, Scandal of the Incarnation: Irenaeus Against the Heresies, ed. oleh Hans Urs von Balthasar (San Francisco: Ignatius Press, 1990), x. Peter C. Hodgson, "The Incarnation of God: An Introduction to Hegel's Theological Thought as Prolegomena to a Future Christology . Hans Küng , J. R. Stephenson," The Journal of Religion 70, no. 2 (April 1990): 276-79, https://doi.org/10.1086/488364. Pierre Maraval, "Basil Studer, Trinity and Incarnation. The Faith of the Early Church, Translated by Matthias Westerhoff, Edited by Andrew Louth, Edinburgh, T. \& T. Clark, 1995," Revue d'Histoire et de Philosophie religieuses 75, no. 3 (1995): 342. Saint Athanasius, De Incarnatione Verbi Dei: Athanasius On the Incarnation of the Word of God, trans. oleh Sister Penelope Lawson (Religious Tract Society, 1903), x. James KA Smith, Speech and theology: Language and the logic of incarnation (Routledge, 2005), x. Stephen Theron, Thought and Incarnation in Hegel (Cambridge Scholars Publishing, 2020), x.
} 
Catatan di luar Alkitab ada yang melukiskan Yesus sebagai orang bijaksana yang melakukan perbuatan mengherankan dan seorang guru seperti yang dicatat Flavius Yosefus (37-100 M) dalam bukunya Antiquitates. ${ }^{3}$ Catatan Tacitus (56-117 M) pada sekitar tahun $110 \mathrm{M}$ hanya mencatat kematian Yesus sedangkan Claius Plinius Caecilius Secundus (23-79 M) yang sezaman dengan Tacitus hanya menceritakan bahwa umat Kristen pada tahun $110 \mathrm{M}$ telah menyembah Yesus Kristus sebagai Allah. ${ }^{4}$ Pada bagian lain, catatan Rabinik hanya sedikit mencatatat tentang Yesus, selain informasi mengenai penolakan kaum rabinik terhadap pengakuan Yesus bahwa Ia adalah Anak Manusia, catatan mengenai penyaliban dan mukjizat yang dilakukan Yesus, catatan mengenai kebangkitan Yesus dan pernyataan bahwa Yesus adalah seorang ahli sihir. ${ }^{5}$ Selain itu tidak didapat catatan yang memadai untuk mendapatkan gambaran yang lengkap mengenai keberadaan Yesus Kristus. Gambaran mengenai kehidupan Yesus sejak masa kandungan sampai mengakhiri pelayanan-Nya di bumi banyak dipaparkan oleh penulis empat kitab Injil.

Secara garis besar ada anggapan bahwa penulis Injil Sinoptik tidak secara tegas menyatakan Yesus Krisus sebagai Allah dan hanya Injil Yohanes yang memberikan ketegasan bahwa Yesus Kristus adalah Firman yang bersama-sama dengan Allah sejak semula dan berinkarnasi menjadi manusia (Yoh. 1: 1-14). Browning mencatat adanya pandangan bahwa penulis Injil Yohanes telah memasukan penafsiran teologinya ke dalam Injil Yohanes, sehingga memiliki tendensi yang berbeda dengan catatan Injil sinoptik yang lebih mengedepankan

\footnotetext{
${ }^{3}$ W.R.F. Browning, A Dictionary of the Bible (Jakarta: BPK Gunung Mulia, 2009), 491.

4 Browning, A Dictionary of the Bible , 491.

5 Browning, A Dictionary of the Bible, 491.
} 
sisi sejarahnya. ${ }^{6}$ Pengkajian akan esensi pribadi Yesus dijadikan sebagai usaha untuk menemukan fakta yang membuktikan bahwa Yesus hanyalah manusia biasa yang memiliki beberapa kelebihan. Ada pula anggapan bahwa Yesus Kristus adalah Allah yang menjadi manusia merupakan hasil dari pemujaan dan pengkultusan yang berlebihan dari murid-murid Yesus, bahkan Yesus dipandang sebagai pribadi yang terbatas dan pernah salah.

Keraguan dan penyangkalan tentang keberadaan Yesus sebagai Allah yang menjadi manusia dilakukan dengan mengajukan bukti-bukti "teologis" yang sebagian besar merujuk kepada beberapa catatan di dalam kitab-kitab Injil. Hal ini didasari pemikiran bahwa beberapa ratus tahun setelah Yesus menyelesaikan pelayanannya maka para murid dan pengikut Yesus telah menyuarakan bahwa Yesus merupakan sosok ilahi yaitu Allah yang menjadi manusia, sehingga muncul anggapan bahwa catatan-catatan Perjanjian Baru berisi tentang pemujaan dan pengkultusan kepada Yesus, yang berimplikasi kepada pemikiran teologis bahwa Yesus bukanlah Allah yang menjadi manusia melainkan seorang utusan Allah yang diberi kuasa oleh yang mengutusnya. Perjanjian Baru memperlihatkan beberapa kisah di mana Yesus Kristus memiliki keterbatasan dalam pengetahuanNya, antara lain: Pertama, Yesus Kristus tidak mengetahui siapa orang yang telah menjamah jubahnya, sehingga ada kuasa yang keluar dari-Nya seperti yang tercatat dalam Markus 5: 30-32 (bdk. Luk. 8: 45). Pemaparan Lukas ini menguatkan tulisan Markus dimana Yesus terlihat memiliki keterbatasan untuk mengetahui siapa yang telah menjamah jubah-Nya. Hal ini telah melahirkan pemikiran bahwa Yesus bukanlah pribadi yang mahatahu melainkan hanyalah 
manusia yang memiliki pengetahuan terbatas. Kedua, Yesus tidak mengetahui mengenai masa depan khususnya kapan akhir zaman terjadi. Penulis Injil Markus memperlihatkan ketidaktahuan Yesus mengenai kapan akhir zaman terjadi (Lih. Mrk. 13: 29, 32).

Beberapa bagian dari kitab Perjanjian Baru yang dianggap menyajikan bukti bahwaYesus pernah melakukan kesalahan. Pertama, Yesus dipercaya salah menyebutkan nama seseorang di mana Yesus Kristus menyebut nama Zakharia anak Berekhya-lah sebagai orang benar yang dibunuh di antara tempat kudus dan mezbah (Mat. 23: 35). Dalam catatan 2Tawarikh 24: 20, Zakharia anak Yoyadalah yang mati di antara tempat kudus dan Mezbah. Kesalahan ini dianggap fatal dan menjadi bukti kuat bahwa Yesus bukanlah Allah yang menjadi manusia. Kedua, Yesus dianggap melakukan perbuatan tercela dan berdosa ketika Yesus marah dan membalikkan meja-meja pedagang di Bait Allah (Mat. 21: 12-16; Luk. 19: 45-46; Yoh. 2: 13-17). Ketiga Injil menuliskan cerita yang berkonotasi sama yakni bahwa Yesus sangat marah terhadap para pedagang yang berjualan di halaman Bait Allah (Mat. 21: 12; Luk. 19: 45; Yoh. 2: 15-16). Sikap Yesus yang marah di khalayak umum dengan membalikkan meja para pedagang dianggap perbuatan yang tidak pantas dan lahir dari seseorang yang tidak memiliki pengendalian diri. Perbuatan tersebut dianggap bukanlah perbuatan sosok ilahi yang penuh pengendalian diri, penuh kasih dan mahasempurna. Tindakan Yesus tidak hanya dianggap tindakan yang reaktif melainkan juga tindakan tercela karena tidak etis dan mengganggu ketenangan masyarakat. Oleh karena itu, penelitian tentang konteks tersebut diperlukan untuk melihat gambaran mengenai siapa Yesus yang sesungguhnya. 


\section{METODE}

Artikel ini menggunakan pendekatan teologis-apologetis, artinya metode ini menjelaskan data yang diperoleh secara teologis dari suatu problematika dan disertai pembelaan terhadap keberatan sebuah argumen. Artinya, metode kualitatif tetap mengandalkan data berupa teks, dan memiliki langkah-langkah analisis terhadap data yang diperoleh. ${ }^{7}$ Metode kualitatif mengandung karakteristik seperti mengamati apa yang dibutuhkan, mengumpulkan data melalui dokumentasi dari berbagai sumber, mempelajari makna dari sumber-sumber tersebut, menginterpretasikan, dan memberikan gambaran holistik. ${ }^{8}$ Berangkat dari penjelasan di atas, maka penulis membaca dan menganalisis berbagai literatur yang membahas tentang kontroversi kesalahan dan keterbatasan Yesus dalam skema kemanusiaan, selanjutnya merangkum berbagai konteks kontroversi dalam berbagai pandangan dan literatur serta memberikan poin-poin penegasan teologisapologetis.

\section{HASIL}

Penelusuran literatur memberikan hasil penelitian sebagai berikut: Pertama, tidak ditemukan bukti teologis yang kuat bahwa Yesus memiliki keterbatasan dalam pengetahuan-Nya berkaitan dengan siapa orang yang menerima kuasa-Nya melalui sentuhan terhadap jubah (Mrk. 3: 30; Luk. 8: 45) dan mengenai kapan akhir zaman terjadi (Mrk. 13: 29, 32). Kedua, tidak ditemukan bukti teologis yang kuat bahwa Yesus pernah melakukan kesalahan

7 John Creswell, Penelitian Kualitatif dan Desain Riset: Memilih di antara LIma Pendekatan (Yogyakarta: Pustaka Pelajar, 2015), 245. Lih. Handi Hadiwitanto, "Metode Kuantitatif dalam Teologi Praktis," Gema Teologika 2, no. 1 (28 April 2017): 1, https://doi.org/10.21460/gema.2017.21.291.

8 Creswell, Penelitian Kualitatif dan Desain Riset: Memilih di antara LIma Pendekatan, 247-49. 
ketika salah menyebutkan nama seseorang yaitu Zakharia anak Berekhya (Mat. 23: 35; 2Taw. 24: 20) dan menyatakan kemarahan di Bait Allah (Mat. 21: 12-16; Luk. 19: 45-46; Yoh. 2:1 3-17). Pada bagian lain, apa yang dilakukan Yesus di Bait Allah merupakan tindakan yang tepat dan terukur karena Ia tidak menyerang orang melainkan perilakunya yaitu pedagang di Bait Allah.

\section{PEMBAHASAN}

Pribadi Yesus Kristus menjadi sosok yang telah melahirkan kontroversi teologis yang telah berlangsung selama ribuan tahun. Keunikan diri-Nya yang dinyatakan melalui kebangkitan-Nya menjadi penanda bahwa Allah Trinitas telah mengubah esensi natural manusia yang berujung pada kematian kekal, menjadi manusia yang mulia yang terbebas dari kematian kekal. ${ }^{9}$ Perjalanan kehidupan Yesus Kristus kematian dan kebangkitan bukan hanya berbicara mengenai karya keselamatan melainkan juga menyatakan keberadaan Allah Tritunggal. ${ }^{10}$

Keberadaan Yesus sebagai manusia diakui oleh semua orang-orang yang hidup sezaman-Nya dan Yesus memiliki jalur kekeluargaan yang jelas dan meneguhkan keberadaannya. ${ }^{11}$ Penulis kitab Injil yang banyak memaparkan kehidupan Yesus sejak sejak masa kanak-kanak sampai Ia mengalami kematian di kayu salib juga banyak mencatat kegiatan Yesus sebagai seorang manusia seperti makan, minum, tidur dll. Beberapa catatan kitab-kitab Injil yang mencatat aktivitas sebagai manusia sebagaimana manusia lainnya, antara lain: Yesus

9 Yap Fu Lan, "Allah Trinitaris Dalam Refleksi John Zizioulas," Diskursus - Jurnal Filsafat Dan Teologi Stf Driyarkara 13, No. 2 (20 Oktober 2014): 230-31, Https://Doi.Org/10.36383/Diskursus.V13i2.81.

${ }_{10}$ Budi Hartono, "Inspirasi, Abstraksi, Dan Historisasi Doktrin Trinitas," Diskursus-Jurnal Filsafat Dan Teologi Stf Driyarkara 10, no. 2 (2011): 227, https://driyarkara.ac.id/jurnaldiskursus/index.php/diskursus/article/view/192/108. 2019), 242-43.

11 Gerald Bray, Allah Telah Berfirman Sejarah Theologi Kristen, vol. 1 (Surabaya: Momentum, 
makan (Mat. 9: 10-11; 26: 7, bdk. Mrk. 14: 3, 22; Luk. 7: 36-37, 24: 41-43). Yesus minum (Mat. 27: 48; bdk. Mrk. 15: 36; Yoh. 19: 30, 21: 15). Yesus tertidur (Mat. 8: 24 dan Mrk. 4: 38). Aktivitas Yesus ketika makan, minum dan tidur merupakan perilaku yang tidak jauh berbeda dengan perilaku orang-orang pada umumnya, aktivitas manusiwi yang dilakukan Yesus tidak mendatangkan pertanyaan dan kebingungan bagi orang-orang yang disekitar-Nya.

Raymon Brown dan Adrianus Sunarko sepakat bahwa penulis kitab Injil Markus memberikan penekanan yang kuat akan kemanusiaan Yesus, sisi kerendahan-Nya, dan bahkan melihat aspek kemanusiaan Yesus sebagai hal yang penting sebelum penyaliban-Nya. ${ }^{12}$ Pendapat tersebut dapat diterima bahwa penulis kitab Markus menaruh perhatian yang besar akan kemanusiaan Yesus.

Kitab Markus juga banyak mencatat peristiwa yang dilakukan Yesus sebagai sosok ilahi, misalnya: pencobaan yang hebat dari iblis di padang gurun sambil berpuasa selama empat puluh hari lamanya (Mrk. 1: 12-13), mengajar dengan penuh kuasa di rumah ibadah sekaligus mengusir roh jahat yang mengenal Yesus sebagai Yang Kudus dari Allah (Mrk. 1: 21-28), kesembuhan banyak orang dari sakit penyakit dan kerasukan setan (Mrk. 1: 29-34) dan masih banyak perbuatan ajaib yang dilakukan Yesus (Mrk. 1: 40-45; 2: 1-12; 3: 1-12; 4: 35-41; 5: 21-43; 6: 30-44; 6: 45-52; 4: 53-56; 7: 31-37; 8: 1-10; 10: 22-26; 9: 14-29; 10: 46-52).

12 Raymond E. Brown, The Anchor Yale Bible Reference Library. An Introduction To The New Testament (New Haven: Yale University Press, 2010), 83-103 versi pdf. Lih. juga Raymond E. Brown, Jesus, God and Man: Modern Biblical Reflections (London: Geoffrey Chapman, 1968). 87-103. versi pdf; The Deatd of Messiah vol. 1 (New York: Doubleday, 1994); The Deatd of Messiah vol. 2 (New York: Doubleday, 1994); R. M. Fowler, Let the Reader Understand: Reader-Response Criticism and the Gospel of Mark (Minneapolis: A/F, 1991); J. P. Heil, The Gospel of Mark as a Model for Action: A Reader-Response Commentary (New York: Paulist, 1992). J. Marcus, The Way of the Lord: Christological Exegesis of the Old Testament in the Gospel of Mark (Louisville: W/K, 1992). N. Perrin, "Towards an Interpretation of the Gospel of Mark," in Christology and a Modern Pilgrimage, ed. H. D. Betz (Claremont, CA: New Testament Colloquium, 1971). Sunarko, 19-20. 
Perbuatan ajaib yang dilakukan Yesus banyak dicatat oleh penulis Injil Markus, sehingga argumentasi yang menyatakan bahwa penulis kitab Markus menitikberatkan kemanusiaan Yesus dalam Injil Markus sulit dipertahankan. Pemahaman yang lebih baik dapat dibangun dengan melihat pemaparan penulis kitab Markus bahwa Yesus merupakan sosok yang unik dan luar biasa. Yesus merupakan pribadi manusia sejati yang juga memiliki esensi ilahi di dalam diriNya yang melekat secara utuh. Yesus ini juga mampu menghadirkan intervensi ilahi dalam setiap kesulitan yang dihadapi manusia baik sakit penyakit, kebutuhan hidup, kuasa jahat dan menguasai alam.

Penulis Injil Markus mengemukakan catatan yang memiliki keselarasan dengan para penulis Injil lainnya, bahwa Yesus dalam kehidupannya di muka bumi berperilaku sebagaimana manusia sekaligus mampu melakukan hal-hal yang hanya dapat dilakukan oleh pribadi ilahi. Berbagai mukjizat yang dilakukan Yesus bukan hanya mampu menyembuhkan penyakit yang tidak dapat disembuhkan, melainkan juga mampu menghidupkan Lazarus yang telah empat hari berbaring di dalam kubur (Yoh. 11: 17). Peristiwa Yesus membangkitkan Lazarus disaksikan banyak orang Ketika orang banyak itu hendak menghibur Maria dan Marta berkaitan dengan kematian saudara mereka (Yoh. 11: 19). Kisah Lazarus yang dipaparkan secara panjang lebar dan terperinci oleh penulis Injil Yohanes memiliki makna yang mendalam, jika didasarkan pada pemahaman Injil Yohanes bahwa Yesus adalah Firman yang ada bersama Allah pada mulanya dan Firman itu adalah Allah itu sendiri (Yoh. 1: 1-2, 14). Pernyataan bahwa Yesus adalah Allah yang menjadi manusia diperkuat dengan pernyataan Yohanes pembaptis tentang Yesus yang memiliki kedudukan sangat tinggi dan Yesus lah yang layak 
dan memiliki kapasitas untuk membaptis orang dengan Roh Kudus (Yoh. 1: 1533). Oleh karena itu, Brown sebagaimana yang dikutip oleh Sunarko, memberi pernyataan bahwa pemaparan penulis Injil Yohanes yang menekankan sisi keilahian Yesus telah menimbulkan konsekuensi logis di mana sisi kemanusian dan keterbatasan manusiawi Yesus menjadi tidak terlihat. ${ }^{13}$ Seorang bapa gereja yang bernama Klemen dari Aleksandria menyebut Injil Yohanes sebagai Injil spiritual karena Injil ini banyak memuat mengenai ketaatan dan kehidupan rohani sebagai murid-murid Yesus yang dipercaya sebagai Tuhan. ${ }^{14}$ Ketegasan pembukaan Injil Yohanes mengenai hakikat diri Yesus telah menempatkan Injil ini sebagai Injil spiritual yang mengangkat keilahian Yesus sebagai fakta teologis yang harus disadari setiap pembaca Injil tersebut.

Rasul Lukas dalam tulisannya yang kedua yang dikenal sebagai kitab Kisah Para rasul juga membuka pemaparannya mengenai keilahian Yesus. Yesus digambarkan sebagai pribadi yang terangkat ke sorga (Kis. 1: 9-11). Yesus yang pada awal pelayanannya tidak dipercaya dan ditentang orang banyak mendapat pengagungan dari para pengikutnya dan dipercaya sebagai Allah yang menjadi manusia. Peristiwa kenaikan Yesus telah menjadi dasar teologis pengakuan iman para murid bahwa Yesus adalah Tuhan seperti yang diutarakan Petrus dalam khotbah pertamanya setelah peristiwa Pentakosta (Kis. 2: 21-24).

Petrus menyatakan bahwa Yesus orang Nazareth adalah seorang yang telah ditentukan Allah untuk disalib, dibunuh, dilepaskan Allah dari kuasa maut, dibangkitkan dan naik ke surga di sebelah kanan Allah (Kis. 2: 35). Kebenaran itu menempatkan Yesus sebagai pribadi dimuliakan para pengikut-Nya dan yang

${ }^{13}$ Sunarko, Kristologi: Tinjauan Historis-Sistematik, 23. 1992), 9.

14 Gary M. Burge, Interpreting the Gospel of John (Grand Rapids, Michigan: Baker Books House, 
layak disebut sebagai Tuhan dan Kristus (Kis. 2: 36). Pernyataan Petrus tersebut merupakan pernyataan pertama kali yang muncul dari murid Yesus dalam kesadarannya yang utuh. Petrus pernah menyatakan Yesus sebagai Mesias Anak Allah yang hidup sehingga Yesus menyatakan hal itu sebagai pernyataan yang lahir dari Bapa di Sorga (Mat. 16: 16). Akan tetapi, pernyataan ini menjadi kontradiksi karena dalam cerita selanjutnya Petrus mendapat hardikan dari Yesus karena Petrus memperkatakan pernyataan yang bertentangan dengan kehendak Allah. Petrus menyatakan bahwa Yesus seharusnya tidak pergi ke Yerusalem untuk menanggung banyak penderitaan dan mengalami kematian sebagai pernyataan yang bertentangan dengan kehendak Allah (Mat. 16: 21-23). Oleh karena itu, pernyataan Petrus lahir dari pengetahuan yang belum lengkap tentang seluruh rangkaian karya keselamatan bahwa Yesus harus menderita, mengalami kematian, bangkit dan dipermuliakan dalam kenaikan-Nya. Hal ini sangat berbeda dengan pernyataan Petrus di hari Pentakosta yang menjadi salah satu saksi mata dalam rangkaian karya keselamatan yang Yesus kerjakan. Oleh karena Petrus secara tegas dan berani menyatakan bahwa Yesus yang disalibkan itu merupakan Tuhan dan Kristus (Kis. 2: 36).

Penegasan Petrus menimbulkan polemik, ada yang meyakini bahwa Yesus hanyalah manusia unik yang memiliki keterbatasan dan kesalahan sehingga Ia bukanlah Tuhan dan Kristus. Keberadaan Yesus sebagai pribadi ilahi sering dipersoalkan. Asumsinya adalah beberapa bagian memberi indikasi bahwa Yesus adalah pribadi yang terbatas dan tidak maha tahu (Mrk. 5: 30-32; 13: 29-32 dan Luk. 8: 45). Beberapa catatan itu telah menimbulkan asumsi bahwa Yesus bukanlah pribadi ilahi melainkan hanya manusia biasa yang memiliki keunikan 
atau kelebihan dibandingkan manusia lainnya. Akan tetapi, Alkitab tidak mengabaikan fakta-fakta bahwa para penulis Injil mencatat berbagai mukjizat yang Yesus kerjakan. Para penulis kitab Injil menyajikan cerita mengenai Yesus yang bergerak sebagaimana manusia pada umumnya sekaligus Yesus yang bergerak dalam hal-hal yang luar biasa dan ilahi sebagai satu kesatuan yang melekat pada diri Yesus Kristus. Para penulis Injil menyajikan narasi bahwa ada pribadi yang unik dan luar biasa, karena di dalam diri-Nya mampu memanifestasikan dua pernyataan diri sebagai pribadi manusia sekaligus pribadi yang ilahi. Akan tetapi, kasus pertanyaan Yesus mengenai siapa yang telah menyentuh jubah-Nya sehingga ada kuasa yang keluar dari diri-Nya seakan-akan menjadi bukti yang tidak terbantahkan bahwa Yesus adalah pribadi yang terbatas dan tidak maha tahu.

Kajian yang seksama, positif dan konstruktif terhadap kasus ini memperlihatkan bahwa penulis Injil Markus dan Lukas justru ditampilkan sebagai pribadi yang memiliki pengetahuan yang lebih dibandingkan manusia biasa. Rasul Lukas menyatakan bahwa Yesus tahu ada yang menyentuh-Nya, justru orang banyak dan para murid khususnya Petrus sama sekali tidak mengetahui bahwa ada orang yang menyentuh Yesus (Luk. 8: 45). Akan tetapi, Yesus secara tegas menyatakan bahwa ada orang orang yang menjamah-Nya, dengan bukti ada kuasa yang keluar dari diri-Nya. Kata merasa ini dapat diterjemahkan sebaagai bahwa Yesus tahu dan sadar sehingga Ia yakin bahwa ada yang menjamah diri-Nya. ${ }^{15}$

Penegasan Yesus mengandung pengertian bahwa Ia menginginkan ada pengakuan dari orang yang telah menjamah diri-Nya. Hal ini membuahkan hasil

15 J. Reiling dan J.L. Swellengrebel, Pedoman Penafsiran Injil Lukas (Jakarta: LAI \& Yayasan Bakti Budaya, 2005), 289. 
melalui pengakuan seorang perempuan yang telah menderita pendarahan selama dua belas tahun (Luk. 8: 47; bdk 8: 43). Dalam narasi ini terlihat secara konkrit bahwa Yesus menyatakan diri-Nya sebagai pribadi yang penuh kuasa melalui suatu cerita yang alur nya terus meningkat mencapai klimaks dimana Yesus ditampilkan secara utuh sebagai pribadi yang berkuasa (Mrk. 5: 25-34; Luk. 8: 45). Dalam narasi ini sosok Yesus ditampilkan penulis Injil Markus dan Injil Lukas sebagai pribadi yang ditampilkan secara perlahan-lahan dan natural dari sosok manusia biasa menuju sosok yang memiliki kuasa dan ilahi.

Sensitivitas akan sosok Allah yang menjadi manusia berusaha ditampilkan penulis secara progresif, untuk membangun kesadaran iman yang kuat dari para pengikut Yesus. Yesus yang lahir sebagaimana manusia lainnya memiliki keistimewaan karena kelahirannya sudah dinubuatkan dan diberitahukan sebelumnya (Yes. 7: 14; Mat. 1: 23, 2: 10; Hos. 11: 1; dll). Yesus yang bertumbuh sebagai manusia sejati mulai menyatakan keunikannya ketika Ia memulia pelayanNya yang banyak dihiasi cerita yang luar biasa. Pelayanan Yesus yang luar biasa ditulis secara gradual untuk membangun suatu pemahaman dan kesadaran bahwa Yesus bukan hanya manusia biasa melainkan juga pribadi yang ilahi. Oleh karena itu, penulis kitab Injil tidak serta merta menghilangkan sisi kemanusian Yesus ketika Yesus menyatakan hal-hal yang ilahi. Secara cermat dan sengaja penulis Injil dalam beberapa catatannya menampilkan sisi kemanusiaan dan keilahian Yesus ditampilkan secara bersama-sama untuk membangun pemahaman teologis bahwa Yesus adalah manusia sejati sekaligus Allah sejati.

Kritikan akan keberadaan Yesus terasa semakin kuat ketika Yesus dinyatakan sebagai pribadi yang terbatas karena Ia tidak mengetahui kapan akhir 
zaman terjadi (Mrk. 13: 29-32). Pendapat ini dapat dibenarkan apabila dimulai dari cara berpikir bahwa Yesus adalah manusia belaka (starting poin). Akan tetapi, kasus ini akan memunculkan pandangan yang berbeda ketika pembacaan Markus 13: 29-32 berangkat dari pemikiran bahwa kehadiran Yesus di tengah dunia memiliki tugas esensial sebagai juru selamat manusia. Kehadirannya di tengah dunia tidak untuk menyatakan tentang kapan akhir zaman terjadi, walaupun Yesus memberikan pengajaran tentang tanda-tanda yang terjadi sebelum akhir zaman terjadi (Mat. 24-25: 46).

Pengajaran Yesus tentang akhir zaman yang tercatat dalam Matius 24: 2931 memang menyatakan bahwa Anak manusia akan datang kembali di akhir zaman akan tetapi tugas anak manusia tidak untuk menyatakan kapan hal itu akan terjadi (Mat. 24: 29-31). Kedatangan Anak manusia yang pertama dalam rangka melaksanakan karya keselamatan dan bukan untuk memberi tahu kapan akhir zaman terjadi. Akhir zaman terjadi ada dalam pernyataan Allah Bapa. Hal ini memperlihatkan keharmonisan keberadaan Bapa, Anak dan Roh Kudus dalam kesatuannya yang harmonis. Komitmen masing-masing Pribadi Allah Tritunggal terhadap peran dan fungsinya tidaklah menjadi bukti keterbatasan masing-masing, melainkan pernyataan diri yang harmonis dan sempurna. Oleh karena itu, pernyataan Yesus bahwa Ia tidak mengetahui kapan akhir zaman terjadi tidaklah serta merta dipahami sebagai bukti keterbatasan Yesus melainkan sebagai bukti komitmen Sang Anak untuk berperan dan berfungsi sebagai juru selamat dan hakim di akhir zaman bukan sebagai pribadi yang menyatakan kapan akhir zaman terjadi. 
Kekristenan menjadi suatu sistem kepercayaan yang unik ketika Yesus sebagai tokoh sentral kekristenan membawa berita cinta kasih sebagai pesan utama dalam kepercayaan yang diajarkan-Nya. Para penulis kitab Perjanjian Baru menyajikan kisah-kisah cinta kasih dan semangat nirkekerasan yang diajarkan Yesus Kristus di dalam mewartakan kekristenan. Dapat juga dipahami bahwa Yesus menunjukkan ketegasan-Nya dalam pengajaran-Nya yang tak kenal kompromi. Rasul Lukas memberi penekanan yang kuat dan terperinci bagaimana Yesus menyikapi kejahatan yang dilakukan musuh-musuhnya dengan sikap yang nirkekerasan dan pengampunan tanpa menyiratkan semangat pembalasan (Luk. 23: 34). Rasul Matius dan Markus menyajikan pengajaran Yesus tentang cinta kasih dan hidup yang nirkekerasan dikaitkan dengan relasi antara pengikut Yesus dengan komunitas di lingkungannya (Mrk. 9: 50; Mat. 10: 13). ${ }^{16}$

Sikap hati untuk senantiasa berdamai dengan sesama merupakan suatu format hukum ilahi yang harus diterapkan dalam seluruh aspek kehidupan umat Allah termasuk area kehidupan politik yang cenderung dianggap sebagai bidang kehidupan yang korup dan jahat. Orang Kristen harus menjadi pribadi pembawa dan pembuat perdamaian dalam seluruh situasi kehidupan baik dalam relasi antar pribadi, antar komunitas dan antar negara. Yesus dalam pengajarannya terlihat menentang segala bentuk perlawanan terhadap kejahatan. Yesus hanya memperlihatkan perilaku yang konfrontatif terhadap hal-hal yang bersentuhan langsung dengan eksistensi kekudusan Allah. Yesus pernah melakukan tindakan yang konfrontatif ketika bait Allah di Yerusalem memiliki fungsi ganda sebagai tempat kegiatan rohani sekaligus pusat perdagangan, bahkan perdagangan gelap

16 Joel B. Green, Scot McKnight, dan Howard Marshal, Dictionary of Jesus And The Gospel (Leicester: Intervarsity Press, 1992), 604-5. 
dan pencucian uang (Yoh. 2: 13-25). Tindakan Yesus yang sangat keras ini lahir dari fakta bahwa bait Allah tidak lagi berfungsi sebagai pusat penyembahan kepada YHWH melainkan berfungsi sebagai pusat perdagangan. Hal ini terlihat dari adanya transaksi pertukaran uang yang cenderung bersifat spekulatif sehingga dapat mengganggu citra bait Allah sebagai pusat pengajaran tentang kebenaran dan kekudusan. ${ }^{17}$ Oleh karena itu, tindakan Yesus yang sangat keras tidak dapat ditafsirkan sebagai tindakan yang bertentangan dengan pengajaran cinta kasih yang diajarkan-Nya. Cinta kasih yang diajarkan Yesus bukanlah sebuah ajaran yang membiarkan keberadaan Allah dan kekudusannya dipermainkan oleh manusia. Sikap tegas dari Yesus terhadap para pedagang di bait Allah merupakan peringatan bagi semua pihak yang meremehkan keberadaan Allah. Tindakan Yesus dalam perpektif sosiologis dan politis pada saat itu merupakan suatu tindakan yang yang benar karena wilayah tempat ibadah merupakan wilayah yang diakui oleh masyarakat dan imperium Romawi sebagai area dikhususkan untuk orang Israel berkaitan dengan kepercayaannya.

Yesus merupakan orang Israel asli dilihat dari sisi hereditas sehingga memiliki legitimasi untuk beraktivitas di area bait Allah (Mat. 1: 1-17). Yesus juga menjalani seluruh prosesi sakramen agama sejak kecil dimana Yesus menjalani prosesi penyunatan ketika Yesus berusia delapan hari dan menjalani prosesi pentahiran dan penyerahaan anak kepada Allah sesuai tradisi keagamaan Yahudi (Luk. 2: 21-24). Oleh karena itu, Yesus memiliki legitimasi yang kuat dari sisi sosiologis dan teologis untuk beraktivitas di Bait Allah termasuk membersihkan bait Allah dari kegiatan-kegiatan yang dapat merusak citra bait

17 Donald Guthrie, "Yohanes," dalam Tafsiran Alkitab Masa Kini, trans. W. B. Sijabat, vol. 3 (Jakarta: YKBK, 1994), 10. 
Allah sebagai pusat peribadatan kepada Allah. Yesus melihat aktivitas perekonomian yang cenderung manipulatif seperti penukaran uang telah mengubah fungsi bait Allah dari pusat peribadatan menjadi pusat perdagangan dan pusat pencucian uang. Oleh karena itu, Yesus sebagai pribadi yang mencintai rumah Allah berkewajiban untuk mengembalikan fungsi dasar bait Allah kembali menjadi pusat peribadatan dan pusat pengkajian taurat Allah. Tindakan Yesus di bait Allah menimbulkan gejolak sosiologis dan teologis dari kaum Yahudi yang ada di sekitar bait Allah tetapi Rasul Yohanes dalam catatannya memberi indikasi yang kuat bahwa orang-orang Yahudi tersebut tidak membawa tindakan Yesus ke ranah hukum.

Hal ini menyiratkan bahwa tindakan Yesus merupakan tindakan yang benar dilihat dari sisi komunitas Yahudi baik dari aspek sosiologis maupun aspek teologis. Prasangka negatif terhadap pribadi Yesus hanyalah respon reaktif dan negatif dari segelintir orang yang merasa dirugikan oleh tindakan Yesus. Yesus tidak melakukan perbuatan pidana karena tidak menganiaya para pedagang melainkan membersihkan ruang pelataran dari barang-barang yang tidak sepantasnya ada di area tersebut seperti kambing, domba, lembu dan uang untuk penukaran uang (Yoh. 2: 15). Kekerasan tidak identik dengan dosa karena kekerasan dapat berfungsi untuk menghentikan ketidakadilan dan kenajisan dalam rangka membentuk kehidupan yang lebih baik. Tindakan kemarahan Yesus di Bait Allah bukanlah suatu kesalahan melainkan tindakan yang benar karena perbuatan para pedagang dan para imam yang melegalkan perdagangan di Bait Allah merupakan tindakan yang tidak dapat ditolerir. Yesus bukanlah tokoh yang bersalah dalam narasi di Bait Allah itu melainkan para imam yang melegalkan 
perdagangan dan pencucian uang di Bait Allahl yang menjadi pihak bersalah. Yesus Kristus adalah pribadi yang sempurna di dalam menjaga kesucian rumah Allah dengan tidak mentolerir segala bentuk penyimpangan yang terjadi.

Penulis Injil Matius dalam bagian ini memaparkan pernyataan Yesus mengenai sejarah orang Yahudi yang diisi dengan kisah pembunuhan terhadap orang-orang benar dan utusan Allah (Mat. 23: 34). Kisah pembunuhan Habel menjadi kisah kelam di awal sejarah manusia karena Habel sebagai orang benar mengalami pembunuhan dari saudaranya Kain yang cemburu kepadanya. Yesus juga menyatakan kisah Zakaria anak Berekhya yang dibunuh diantara tempat kudus dan mezbah sebagai fakta kesadisan orang Yahudi terhadap orang benar. Hal itu akan mencapai klimaksnya dalam kisah pembunuhan Yesus di kayu salib (Mat. 23: 35-37). Pernyataan Yesus ini menjadi bahan kontroversi yang dijadikan salah satu bukti kesalahan yang pernah dilakukan oleh Yesus dalam menyebutkan nama Zakharia anak Berekhya yang seharusnya Zakharia anak Yoyada (2 Taw. 24: 20-22). Apakah memang dalam konteks tersebut Yesus salah mengutip atau disebabkan karena kesalahan penyalinan naskah PB? Dalam kaitannya dengan kritik teks, Bart D. Ehrman berpendapat bahwa, adanya perubahan terbanyak adalah perubahan karena kesalahan murni dan sederhana, seperti salah tulis, pengurangan atau penambahan yang tidak disengaja, kesalahan ejaan dan kesalahan-kesalahan kecil lain. ${ }^{18}$ Bruce Metzger dan Ehrman menemukan beberapa jenis kesalahan karena adanya penglihatan atau pendengaran kurang baik, dan kesalahan karena cara berpikir. ${ }^{19}$

18 Bart D Ehrman, Misquoting Jesus: The Story behind Who Changed the Bible and Why (San Francisco: Harper Collins Publishing Inc, 2005), 55.

${ }_{19}$ Bruce M. Metzger dan Bart D Ehrman, The Text of the New Testament: Its Transmission, Corruption, and Restoration, 4 ed. (Oxford: Oxford University Press, 2005), 250-59. 
H. L. Ellison menuliskan bahwa Injil Lukas hanya menyebut Zakharia tanpa disertai keterangan anak Berekhya seperti yang ditulis oleh Matius. ${ }^{20}$ Lukas memfokuskan ceritanya kepada kejadian di akhir zaman bukan kepada keberadaan Zakharia dalam kaitannya dengan silsilah Zakharia. D. A Carson memberikan beberapa alternatif jawaban di dalam penyelesaian kontroversi mengenai Zakharia anak Berekhya ini, antara lain: Pertama, Zakharia yang dimaksud Yesus bukan ayah dari Yohanes pembaptis. Kedua, Zakharia yang dimaksud Yesus adalah Zakharia anak Baris atau Baruch atau Bariscaeus orang Zelot yang mati di Bait Allah seperti yang pernah ditulis oleh Yosephus seorang sejarahwan Yahudi. Akan tetapi, pendapat ini tidak didukung bukti yang kuat bahwa Zakharia yang dimaksud oleh Yosephus adalah seorang nabi Allah atau seorang martir. Ketiga, Zakharia yang dimaksud oleh penulis kitab Injil adalah Zakharia yang tidak dikenal? Hal ini dimungkinkan tetapi pendapat ini juga tidak memiliki bukti yang kuat. Keempat, Zakharia yang dimaksud adalah nabi Zakharia anak Berekhya (Zak. 1: 1). Zakharia mendapat ikatan keluarga dari ayahnya sehingga disebut Zakharia anak Berekhya, sedangkan Yoyada diperkirakan adalah kakek dari nabi Zakharia (Zak. 1: 1; Ez. 6: 14; bdk. 2Taw. 24: 15). Namun pendapat ini juga memiliki kelemahan karena tidak ditemukan bukti yang kuat bahwa Nabi Zakharia mati terbunuh di Bait Allah. ${ }^{21}$

Akan tetapi, pengkajian yang saksama memberikan beberapa pemikiran kritis yang perlu dicermati oleh para pembaca kitab suci, antara lain: Pertama, Apakah nama Zakharia anak Berekhya seperti yang tercatat dalam Matius 23:35

20 H. L. Ellison, The International Bible Commentary, ed. oleh F.F. Bruce (Grand Rapids, Michigan: Zondervan Publishing House, 1979), 1143.

21 D. A. Carson, Expositor's Bible Commentary: Matthew \& Mark, Volume 9 (Grand Rapids, Michigan: Zondervan Publishing House, -), 545. 
pasti merujuk atau harus disematkan kepada Zakharia anak Imam Yoyada seperti yang tercatat pada 2Tawarikh 24: 20-22, sehingga dipastikan bahwa Yesus telah melakukan kesalahan penyebutan inisial seseorang? Apakah para pembaca kitab suci tidak boleh memahami Zakharia anak Berekhya yang tercatat dalam Matius 23: 35 adalah seorang imam yang dikenal oleh ahli-ahli Taurat dan orang-orang Farisi dan dibunuh oleh golongan mereka walaupun tidak tercatat dalam kitabkitab Perjanjian Lama. Peluang untuk menafsirkan seperti itu terlihat dari pernyataan Yesus kepada ahli-ahli taurat dan orang Farisi dalam Matius 23: 35. Indikasi ini terlihat dari tidak adanya respons korektif dari ahli taurat dan kaum Farisi terhadap pernyataan Yesus mengenai nama Zakharia anak Berekhya, sehingga dapat ditafsirkan bahwa Yesus tidak melakukan kesalahan dalam penyebutan nama Zakharia anak Berekhya. Zakharia anak Berekhya yang dimaksud oleh Yesus pastilah seseorang yang dikenal dan diketahui kisahnya oleh para ahli aurat dan orang Farisi sebagai orang yang dibunuh diantara tempat kudus dan mezbah, walaupun mungkin tidak tercatat dalam kitab Perjanjian Lama.

Kedua, pokok persoalan yang disampaikan Yesus dalam dialog yang keras dengan ahli taurat dan orang Farisi bukanlah masalah identitas tokoh-tokoh yang disebut oleh Yesus melainkan kepada kisah kejahatan orang Yahudi terhadap orang benar dan utusan Allah (Mat. 23: 34). Sekalipun ada kesalahan penyebutan nama salah satu tokoh dalam bagian ini, tetapi hal itu tidaklah mengganggu pesan mendasar yang hendak disampaikan oleh Yesus kepada para ahli taurat dan orang Farisi. Ketiga, persoalan penyebutan Zakharia anak Berekhya yang menurut beberapa teolog merupakan kesalahan penyebutan oleh Yesus merupakan suatu tuduhan tendensius. Hal ini lahir dari pemikiran bahwa dalam kesalahan yang 
dimaksud oleh beberapa teolog tersebut mengandung dua kemungkinan, yaitu: Kemungkinan pertama Yesus yang melakukan kesalahan penyebutan inisial seseorang yang seharusnya Zakharia anak Yoyada tetapi disebutkan sebagai Zakharia anak Berekhya. Kemungkinan kedua penulis Injil Matiuslah yang melakukan kesalahan di dalam pencatatan cerita tersebut. Kemungkinan ketiga adanya kesalahan penyalinan dalam proses penyalinan Injil Matius dari sumber tulisan yang mula-mula.

Keyakinan bahwa pernyataan dalam Matius 23: 35 memuat kesalahan yang dilakukan Yesus dalam penyebutan nama Zakharia anak Berekhya bukanlah suatu tuduhan yang memiliki dasar yang kuat. Peluang untuk melakukan kesalahan tersebut lebih besar kemungkinannya dilakukan oleh penulis Injil Matius atau para penyalin kitab suci dari tulisan awal ke dalam bentuk salinan. Penafsiran ini berdasarkan pemahaman bahwa penulis Injil Matius atau para penyalin Injil Matius yang bersentuhan langsung dengan penulisan Injil Matius yang ditulis setelah Yesus bangkit dan naik ke sorga. Anggapan bahwa penulis kitab Injil sebagai pihak yang salah di dalam mencatat kisah tersebut kurang berdasar. Pemahaman ini lahir dari tidak adanya seruan korektif dari ahli-ahli taurat dan orang Farisi di masa itu yang memiliki sejarah dialogis dengan Yesus bahwa Matius melakukan kesalahan atau kekeliruan di dalam penulisan nama Zakharia anak Berekhya. Oleh karena itu, pendapat yang menempatkan penulis Injil Matius sebagai pihak yang melakukan kesalahan sebaiknya ditinggalkan. Penulisan Zakharia anak Berekhya bukanlah suatu kesalahan apabila Zakharia yang dimaksud adalah seorang tokoh yang dikenal oleh orang Farisi walaupun bukanlah seseorang yang pernah tercatat dalam kitab Perjanjian Lama. 


\section{KESIMPULAN}

Kontroversi kemanusiaan dan ketidakbersalahan Yesus dalam ranah teologi perlu ditanggapi dengan cara memahami secara baik konteks penafsiran atas teks-teks yang dianggap sebagai dasar untuk menganggap bahwa Yesus pernah berbuat salah dan Ia bukan Allah yang tak dapat salah. Usaha apologetika yang dikembangkan di sini mengusung dasar-dasar teologis yang kokoh dan penafsiran yang kredibel. Yesus terlihat terbatas bukan karena keberadaannya sebagai seorang manusia belaka yang terbatas melainkan karena komitmen-Nya terhadap tugas pokok dan fungsinya. Keberadaan Yesus sebagai Allah yang menjadi manusia perlu dibangun dari seluruh pernyataan Alkitab dalam kesadaran bahwa para penulisnya menulis dalam kepelbagaian latar belakang dan perspektif tetapi memuat pesan utama yang satu dan menyatu. Para penulis Injil sepakat bahwa Yesus adalah Allah yang menjadi manusia dengan keunikannya sebagai manusia sejati (the Son of Man) sekaligus sebagai Allah sejati (the Son of God).

\section{DAFTAR PUSTAKA}

Athanasius, Saint. De Incarnatione Verbi Dei: Athanasius On the Incarnation of the Word of God. Diterjemahkan oleh Sister Penelope Lawson. Religious Tract Society, 1903.

Bray, Gerald. Allah Telah Berfirman Sejarah Theologi Kristen. Vol. 1. Surabaya: Momentum, 2019.

Browning, W.R.F. A Dictionary of the Bible. Jakarta: BPK Gunung Mulia, 2009.

Burge, Gary M. Interpreting the Gospel of John. Grand Rapids, Michigan: Baker Books House, 1992.

Carson, D.A. Expositor's Bible Commentary: Matthew \& Mark, Volume 9. Grand Rapids, Michigan: Zondervan Publishing House, - .

Creswell, John. Penelitian Kualitatif dan Desain Riset: Memilih di antara LIma Pendekatan. Yogyakarta: Pustaka Pelajar, 2015. 
Daley, Brian E. In the Shadow of the Incarnation: Essays on Jesus Christ in the Early Church in Honor of Brian E. Daley, S.J. Disunting oleh Peter W. Martens. 1 ed. Indiana: University of Notre Dame, 2008.

Davies, Oliver. Silence and the Word: Negative Theology and Incarnation. Disunting oleh Denys Turner. 1 ed. Cambridge: United Kingdom, 2004.

Dunn, James D.G. Christology in the Making: A New Testament Inquiry Into the Origins of the Doctrine of the Incarnation. 2 ed. Grand Rapids: William B Eerdmans Publishing Company, 1996.

Ehrman, Bart D. Misquoting Jesus: The Story behind Who Changed the Bible and Why. San Francisco: Harper Collins Publishing Inc, 2005.

Ellison, H.L. The International Bible Commentary. Disunting oleh F.F. Bruce. Grand Rapids, Michigan: Zondervan Publishing House, 1979.

Fu Lan, Yap. “Allah Trinitaris Dalam Refleksi John Zizioulas.” Diskursus Jurnal Filsafat Dan Teologi Stf Driyarkara 13, no. 2 (20 Oktober 2014): 222-41. https://doi.org/10.36383/diskursus.v13i2.81.

Green, Joel B., Scot McKnight, dan Howard Marshal. Dictionary of Jesus And The Gospel. Leicester: Intervarsity Press, 1992.

Guthrie, Donald. "Yohanes." Dalam Tafsiran Alkitab Masa Kini, diterjemahkan oleh W.B. Sijabat, 3:302. Jakarta: YKBK, 1994.

Hadiwitanto, Handi. "Metode Kuantitatif dalam Teologi Praktis." Gema Teologika 2, no. $1 \quad$ (28 April 2017): 1. https://doi.org/10.21460/gema.2017.21.291.

Hartono, Budi. "Inspirasi, Abstraksi, Dan Historisasi Doktrin Trinitas." Diskursus-Jurnal Filsafat Dan Teologi Stf Driyarkara 10, no. 2 (2011): 213-38. https://driyarkara.ac.id/jurnaldiskursus/index.php/diskursus/article/view/192/108.

Hodgson, Peter C. "The Incarnation of God: An Introduction to Hegel's Theological Thought as Prolegomena to a Future Christology . Hans Küng , J. R. Stephenson.” The Journal of Religion 70, no. 2 (April 1990): 26769. https://doi.org/10.1086/488364.

Horton, Michael. "Affirming Moser's Well-Qualified Totus Christus." Pro Ecclesia: A Journal of Catholic and Evangelical Theology 29, no. 1 (Februari 2020): 43-44. https://doi.org/10.1177/1063851219892188.

Irenaeus. Scandal of the Incarnation: Irenaeus Against the Heresies. Disunting oleh Hans Urs von Balthasar. San Francisco: Ignatius Press, 1990.

Maraval, Pierre. "Basil Studer, Trinity and Incarnation. The Faith of the Early Church, Translated by Matthias Westerhoff, Edited by Andrew Louth, 
Edinburgh, T. \& T. Clark, 1995." Revue d'Histoire et de Philosophie religieuses 75, no. 3 (1995): 342.

Metzger, Bruce M., dan Bart D Ehrman. The Text of the New Testament: Its Transmission, Corruption, and Restoration. 4 ed. Oxford: Oxford University Press, 2005.

Michael. Incarnation and myth: The debate continued. Disunting oleh Goulder. London: SCM Press, 1979.

O'Collins, Gerald. "The Incarnation." Dalam The Incarnation: An Interdisciplinary Symposium on the Incarnation of the Son of God, disunting oleh Stephen T. Davis dan Daniel Kendall, xx. Oxford: Oxford University Press, 2002.

Rea, Michael C., ed. Oxford Readings in Philosophical Theology: Trinity, Incarnation, and Atonement. 1 ed. Vol. 1. Oxford: Oxford University Press, 2009.

Reiling, J., dan J.L. Swellengrebel. Pedoman Penafsiran Injil Lukas. Jakarta: LAI \& Yayasan Bakti Budaya, 2005.

Sanchez, Michelle Chaplin. Calvin and the Resignification of the World Creation, Incarnation, and the Problem of Political Theology in the 1559 Institutes. Massachusetts: Harvard Divinity School, 2019.

Smith, James KA. Speech and theology: Language and the logic of incarnation. Routledge, 2005.

Sunarko, Adrianus. Kristologi: Tinjauan Historis-Sistematik. Jakarta: Penerbit Obor, 2017.

Theron, Stephen. Thought and Incarnation in Hegel. Cambridge Scholars Publishing, 2020. 